\title{
Protecting Prerogative: William III and the East India Trade Debate, 1689- 1698
}

James Bohun

ABSTRACT: Following the Glorious Revolution of 1688, the East India Company struggled to protect its royal monopoly from the challenges of a group of interlopers who had strong support in the House of Commons. The conflict for control of the East India trade had a great effect on the royal prerogative. Historians have presented differing views on the state of the royal prerogative for this period, and positions have remained polarized along conservative and radical lines. Close examination of the East India trade debate sheds much light on the issue. The debate over trade reveals a process of give and take in the struggle over the royal prerogative, with the King giving up certain rights in exchange for Parliamentary support to prosecute the war in France.

The East India Trade debate was a prominent issue before the British House of Commons for nearly two decades. Not simply concerned with the liberty of Englishmen to trade freely, the debate went straight to the heart of the ongoing power struggle between Parliament and the crown. The proponents of freer trade hoped to wrest profits generated by merchant activity in India from the monopoly held by the East India Company and place operations into the hands of a more broadly based consortium. Given that the East India Company's charter had been granted by the crown, an attack on the limited nature of the trade also meant an attack on the King's prerogative to grant such charters. Many of the traditional powers of the crown had been abolished or curtailed in the Revolution Settlement of 1689. Other powers, such as those concerning foreign trade, were left ill-defined in Parliament's effort to prevent a return to Stuart despotism. Thus, while William III lost many customary rights of the British monarchy, he continued to possess great influence over where and how British merchants could trade. It was not yet clear whether foreign trade would remain a prerogative of the crown or revert to Parliamentary control. As a result, when the dispute over the East India trade erupted between a group holding a royal charter and a circle of interlopers supported by Parliamentary majority, the conflict took on ominous constitutional overtones. 
The dispute over the East India trade as it transpired during the reign of William III has been addressed only superficially by scholars. Few works on the topic exist, and these are quite outdated. ${ }^{1}$ Revision is needed in this area. Henry Horwizz did begin to address the lack of attention given to this topic, providing an excellent account of the East India trade debate and how it manifested itself in Whitehall, Parliament, and the constituencies. ${ }^{2}$ Missing from his analysis, however, is the effect that the struggle for control of the East India trade had on the royal prerogative as it related to foreign trade and the granting of commercial monopolies.

The very nature of the conflict over prerogative rights between King and Parliament, moreover, has been difficult to confirm. Historians have been caught between two schools of thought. One group expounds the theory that the Revolution Settlement of 1689 severely curtailed the royal prerogative while the other argues that the King's power to make executive decisions was left virtually intact. ${ }^{3}$ An analysis of the East India trade debate can shed considerable light on the nature of crown-Parliament relations at this time, helping to bridge the gap between these polarized views. ${ }^{4}$

In fact, the East India debate provides the best example of how the King's actions within the realm of foreign trade related to the royal prerogative. As the Company was extremely influential and profitable, yet open to very few subscribers, the Commons saw its charter as a great burden to the nation and its privileges as a contravention of the basic freedoms of England. The debate over the East India Company's charter was not simply a phenomenon of post-1689 England; Parliamencary attacks on monopolies in general date from 1571..$^{5}$ By 1624, Parliament passed the Monopoly Act which made royal patents held by individuals illegal, leaving only those monopolies held by corporations. The East India monopoly began to be targeted as a corporation holding such a monopoly when the 1685 Parliament began assaulting the limited nature of a trade that represented huge profits for those engaged in it.

The pre-revolution debate over the East India trade culminated in the East India Co. v. Thomas Sandys case heard in Trinity term 1683. The case involved the prosecution of an interloper for encroaching upon the Company monopoly but soon ballooned into a dispute between the royal prerogative and those commercial interests barred from the East India trade. In effect, the court ruled on the legality of the monopoly itself. Lord Jeffreys, Chief Justice of the King's Bench, 
heard this momentous case, and ruled for the plaintiff, the East India Company. In his decision he cited the Monopoly Act of 1624 and agreed with the Company's assertion that, since the interlopers had never been in possession of the East India trade, no freedom had been lost nor any liberty restrained. Thus, Common Law upheld the East India Company charter and, by extension, the royal prerogative over foreign trade.

The Sandys case confirmed the royal prerogative in matters of foreign trade, but it was only a preliminary battle in a long war. The new ideas of a King in Parliament and of Parliamencary supremacy, the roots of which lay in the interregnum and restoration periods, blossomed in the glow of 1688. The idea of Parliamentary supremacy dictated that Parliament (in particular the House of Commons) should have a stake in what were formerly royal concerns. When an issue such as the granting and enforcing of royal trading monopolies emerged, an issue not clearly limited to royal interests, the Commons became zealous about defending and strengthening its involvement and influence.

As early as May 1689, petitions against the East India Company practice of seizing interloping ships and their goods reached the House of Commons. ${ }^{6}$ The merchants believed that the Revolution had redefined the Sandys decision, making Parliament the arbiter of their fate. Because the Revolution left the prerogative of foreign trade on a questionable footing, it was assumed that a Parliamentary sanction was required to legitimize any claim to the East India trade. Even the Company acknowledged that the benefit of an act of Parliament was vital to preserving the trade for themselves. Passing such an act was, however, a difficult task to accomplish, although the interlopers, who wanted to break the Company's monopoly charter, had majority support in the Whig dominated Lower House.

It would be convenient to divide interloper and Company support in the Commons along party lines, the former, Whigs, and the latter, Tories. To divide the Members of Parliament in such a way, however, would be to oversimplify the issue. The East India trade debate, according to Henry Horwitz, "cut across both Whig-Tory rivalries and Court-Country differences." Party loyalties were undermined by the ideological ramifications of the issue. The East India debate revolved around the definition of the relationship of the King to Parliament. Thus, the battle over the East India trade was to be fought again, largely on the basis of Parliamentary supremacy 
versus the royal prerogative, with divisions based only partly on party predispositions.

When the Convention Parliament of 1689 received the merchants' petitions, a Committee of the House of Commons was formed "to consider the matter, and the whole affairs of the East India Company." ${ }^{8}$ The Lower House clearly believed that trading concerns were under its jurisdiction, and, therefore, that common law enticled MPs to examine monopolies as stated in the Monopoly Act (1624). ${ }^{9}$ Yet the committee had to walk a fine line, as it was only empowered to examine the abuses of the Company. In any event, the controversy over the East India trade was an emotional one, as suggested by a letter of 7 June 1689 from Richard Yard, a clerk of the State Paper Office. Yard wrote: "It was expected there would be great warmth in the House of Commons to-day, but it passed off, that the business of the East India Company ought to be proceeded with." 10

The "business of the East India Company" was made even more complex by the 1689 decision of Chief Justice Holt in Nightingale v. Bridges, which went a long way towards limiting the royal prerogative. The case involved the right of the Royal African Company to enforce its monopoly through Company courts sanctioned by the crown. In the decision, Holt ruled that the Company could not imprison nor confiscate the goods and ships of interloping traders as "the King cannot by letters patent create a forfeiture of, or any way, by his own act, confiscate a subject's property." In light of this ruling, all royal monopolies and the question of their enforcement appeared to be subject to the common law and Parliament. The decision, then, went against the East India Company policy of punishing interlopers by seizing their goods. Holt's ruling strengthened the cause of the interlopers as they could now legitimately use Parliament as a means of attack against the East India Company monopoly. It also served as a limitation on the prerogative power of the monarch in such charter cases and was, therefore, something that William would have to consider when dealing with the East India question. Rumours of an East India Company dissolution, moreover, had encouraged the interlopers to form into a loose syndicate, strengthening their voice.

With battle lines drawn, a Parliamentary committee was formed in January 1690 to investigate the state of the East India trade and hear arguments for and against the Company monopoly. ${ }^{12}$ The Committee's intent was to make the East India trade more national 
by either opening up the Company for new subscriptions, or dissolving it in favour of a new chartered company. It began by offering an act of Parliament to the existing Company, confirming its royal charter in exchange for an enlarged subscription. The East India Company directors were not prepared to agree to these terms without major concessions, however, so the Committee made the following resolution on 16 January 1690 :

it is the opinion of this Committee, that the best way to manage the East-India trade is to have it in a new Company, and a new Joint Stock, and this to be established by Act of Parliament; but the present Company to continue to trade, exclusive of all others, either Interlopers or Permission Ships, till it be established. ${ }^{13}$

The interlopers had won a major battle in gaining the rights to the East India trade, and immediately subscribed $£ 180,000$ towards a new Company. ${ }^{14}$ The old Company, in response to the resolution above (as well as to Holt's decision in Nightingale v. Bridges), immediately began lobbying for its own act of Parliament to confirm its rights. All was for naught, however, as William suddenly prorogued Parliament on 27 January 1690 and then dissolved it, quelling the issue in the process.

William III did not dissolve Parliament over the East India debate alone, but it did play a role. The Convention Parliament had voted Williams' revenue and declared war on France, but it no longer complied with the King's wishes. Parliament had challenged William on constitutional points, interfering, in particular, in his decision to lead his armies in Ireland. An election was a risky proposition in the unsure political world of post-Revolution England, as an unfriendly House could easily be returned. The election, however, was a gamble William was willing to take. The King was clearly concerned with revenue, and the East India trade was an important source of customs. One East India ship alone could provide over $£ 10,000$ in cax revenue. ${ }^{15}$

The debate came to the fore again in October of 1691 , when the Commons resolved that the East India trade should be carried on by a joint stock company with exclusive privileges confirmed by Parliament. But which company should be given the privileges? This question led to heated Commons debates throughour November and December, culminating in a division on 22 January 1692 in 
which a bill to establish a new East India Company passed by a vote of 171 to $116 .{ }^{16}$ Yet because of strong support in the Lords for the old Company, rather than proceed with the Bill, the Commons majority was forced to ask William to dissolve the old Company and establish a new one "in such manner as his Majesty, in his Royal Wisdom, shall think fit." 17 By 25 February, however, the King had not answered. The Earl of Nottingham, the principal secretary of state, hinted that the King feared a loss in trade (and revenue for the state) if the old Company had to be given three years to wind down. ${ }^{18}$

The fact that the Commons asked the King to form a new Company shows that a certain respect for the prerogative power in this regard still existed. The Nightingale v. Bridgesdecision, however, made it necessary for a royal monopoly to have Parliamentary confirmation in order to be enforceable. Within this framework, the Earl of Nottingham put forth his "Propositions for Regulating the East India Company," involving two principal reforms. The first was that the old Company stock was to be valued at $£ 744,000$ with a new subscription opened to total $£ 1.5$ to 2 million. This measure would provide the interlopers with the opportunity legally to participate in the trade under the existing monopoly charter. Second, individual ownership was to be restricted to $£ 10,000$ worth of stock, which would prevent a small group of shareholders from controlling the Company in the way that Josiah Child, the Company mogul, and his cronies had done. ${ }^{19}$ The old Company directors rejected these reforms.

As a result, the Commons once again asked William to give the old Company its notice. The King was still reluctant to dissolve the present charter, however, due to the loss of trade and revenues. ${ }^{20}$ The courts upheld the right of the East India Company to three years notice before their dissolution, and William feared that trade would be neglected in this period. Therefore, Notringham attempted to regulate the old Company, again along the lines of his Parliamentary sancrioned "Propositions." The old Company refused to agree to these pro-new Company regulations imposed on them by Parliament, which led to a Privy Council resolution on 13 June "that the present East India company should be dissolved, and a charter granted for establishing a new one." ${ }^{11}$ The King, however, remained unconvinced, which leads to the conclusion that his Privy Council was not necessarily made up of his most trusted advisors. Parliamentary encroachments on the prerogative and party politics were evident in Privy Council appointments as well. 
The interlopers seem to have equated William's reluctance to give the old Company notice with his fear of a possible loss of customs revenue over the three year period of grace to which the old Company was entitled. Nottingham, therefore, presented a proposal to the King which involved a loan of up to $£ 200,000$ at legal interest to compensate the crown for lost customs revenues should the old Company be given its notice. By tying the new charter to such a favourable arrangement for the Crown and its finances, Nottingham assured

that the alteration of the company is a good thing, or at least that all the merchants upon the Exchange think so, for otherwise it is not to be imaginned that they would venture so great a summ upon so remote a fond, if it were not also a good one; and it could not be a good one if by this alteration there was any danger that the trade would be lost. ${ }^{22}$

Nottingham's comment illustrates how the King's fear for his customs revenue was perceived as a leading reason for his hesitation to dissolve the old Company.

William rejected the interloper's offer, with one of his courtiers arguing that: " $[t]$ he King does not think of any loan upon this occasion, it being no more than an anticipation of the revenue of the customs upon very little more easy terms than may be at any time had..." ${ }^{23}$ The King did agree, however, that the old Company should be dissolved if the latter refused to accept a new charter which would allow for an expanded subscription. As a result, Parliament and the Privy Council committee led by Nottingham pressed the monarch to recharter the old Company on their terms. Throughout these discussions, Parliament believed itself more qualified than the Court to deal with the issue of the East India trade. Nottingham expressed this idea in a letter to Blathwayt: "I wish his Majesty may so determine this matter as may be most for the satisfaction of the Parliament, which in this particular I believe will be most for his service, and the publick interest of the nation." ${ }^{24}$ Yet, in the late summer of 1692, the King, still concerned about disjointing the trade and depleting his revenues, was not so easily convinced. In fact, William attempted to force a new East India Company charter through Parliament in August 1692 that was virtually unchanged from the existing one. The committee answered that because "this 
matter can't be dispatched before the meeting of Parliament," the issue should be dropped. ${ }^{25}$ Nottingham also made it clear that the terms were unacceptable to the Commons. In the end, William returned the issue to the new Parliamentary session of October 1692, where he hoped it would remain.

The King had averted the problem of settling the East India trade without having Parliament dictate who should possess it. By favouring the old Company he had seemingly defended his royal prerogative and guaranteed his customs revenue. Yet there may have been ocher factors behind the King's decision. First, although Nottingham was a supporter of the new Company, other ministers were not. Lord Godolphin and the Earl of Rochester were both against the dissolution of the old Company. ${ }^{26}$ Furthermore, the Earl of Portland, one of William's confidants, received old Company money for services rendered ${ }^{27}$ Bribery of senior ministers, involving enormous sums, could thus have influenced the King's decision. Yet fear over a possible loss in trade, and the loss of customs which would go with it, seems to have been the main concern behind William's pro-old Company stand.

The rivalry between the two Company factions in Parliament remained great, prompting Nottingham to write that "I pray God the King do not find the ill effects of it [the East India charter failure] in the next sessions. ${ }^{28}$ These words were to prove prophetic, for one of the first issues to emerge on the opening of the session in November 1692 was the East India trade debate. On 14 November, William finally responded to the Commons address of the previous February asking for a dissolution of the old Company. The King refused to do so, citing the opinion of his judges that the old Company must be given three years notice before abrogating its charter. The only option left to the King in these circumstances was once again to ask Parliament to consider the terms of a new charter for the old Company.

In response to the King's wishes, the government submitted a bill to regulate the East India trade before Parliament. A Commitree of the Whole House was formed on 24 November 1692 to consider the specifics of a new East India Company charter to be based upon those put forth in the previous session. To many MPs, the very health of the economy was at stake, with the old arguments of joint stock versus regulated trade dominating much of the discussion in the Lower House. Eventually Parliament decided upon a joint stock 
format, with the old Company supporters proposing that the stock scheme be granted "exclusive of all others." The old company supporters were, however, defeated on this point in a division. ${ }^{29}$ Debate upon the rest of the charter's terms lasted for weeks, with a bill cabled on 10 December.

This bill went against the old Company interests in many ways. The most contentious clauses more than doubled the existing stock of $£ 744,000$ and limited all stock holders to one vote within the Company's General Court instead of one vote per $£ 500$ of stock owned. ${ }^{30}$ To Josiah Child and his friends, who controlled the Company, these terms were unacceptable. The bill would allow a large percentage of the interlopers into the trade, broadening control of it and reducing the profits of the Court of Directors in the process. Essentially, the bill proposed an entirely new Company under the guise of a more open old Company. But the bill lacked clarity; it did not stipulate when the new Company should begin operations or how the interests of the old Company were to be preserved. The bill was therefore referred back to a Committee of the Whole House on 19 December for further consideration. ${ }^{31}$

At this point, the old Company supporters in the Lower House successfully resorted to delaying tactics. Realising the futility of passing the bill prior to the end of the session, the dominant pronew Company interest in the Commons decided to request that the King dissolve the old Company rather than proceed with the bill. As Luttrell records, several MPs

\begin{abstract}
moved that since there was no probability to pass a bill this sessions to establish an East India Company by reason the sessions was pretty near an end and the friends to the old Company give such delays to the bill now in the House, that the House would come to a resolution to address to His Majesty to dissolve the present East India Company, pursuant to the power reserved by a clause in the charter at three years' end after notice. ${ }^{32}$
\end{abstract}

The House so resolved on 25 February 1693. As the old Company had support in the Upper House where any Commons bill concerning trade could be defeated, the address was a logical course of action for new Company adherents to further their cause.

The King was now unable to avoid deciding the fate of the East India trade. The old Company had forced consideration of the issue 
out of Westminster into the hands of William's advisors, where the Company believed it had a greater chance of success in gaining its desired charter. In a sense, then, William was compelled to exercise his prerogative with regard to foreign trade when he had hoped to leave a decision on the East India trade to Parliament. He had tried to place the responsibility of settling the trade upon the Commons, yet the latter remained divided on the issue of the old Company charter. He would, therefore, have to settle the charter himself, while Parliament was prorogued.

The King was not solely concerned with the prerogative of foreign trade; he did show concern for his prerogative in other matters. Lord Godolphin's intelligence letter of 1693, informing William of Tory support for, and Whig opposition to, maintaining the royal prerogative, suggests that the King was concerned with defending his executive powers from Parliamentary factions. ${ }^{33}$ As William and his advisors did defend his prerogative in many areas, it is fair to assume that he must have had reason to remit the East India trade, an issue that fell within his powers, to Parliament. In this case, approval for the charter by both trading interests was proving difficulc to obtain. William, therefore, used Parliament in an attempt to smooth the rough seas upon which the charter was afloat. Both Companies had great incerests in the Commons, which could have agreed on a peaceful settlement, stabilizing the trade and securing the revenue needed to prosecute the continental war. The state of customs was more imperative than the question of limits on the prerogative over foreign trade.

Upon the ending of the session of Parliament 14 March 1693, William, with the help of his ministers, once again considered the East India trade issue. On 16 March, Nottingham called a meeting of the Committee of Privy Council, which had been appointed to consider the affairs of the old Company. Those invited to attend included the Governor of the old Company and Sir John Houblon, a City Whig with ties to the new Company. An initial agreement may have been reached here, as shown by the old Company Court records:

in or about the month of March last His Majesty was pleased to send down to the Company Heads of Regulations for increasing their Stock and for the better carrying on their trade to the East Indies, which were agreed on, submitted to and accepted off by them. ${ }^{34}$ 
In view of this report, it appeared that the issue had been settled. As both the old and new Companies had been represented in the Committee discussion on the matter, Parliamentary confirmation of this charter should have followed quickly. The hopes of an easy solution were ended, however, by the failure of the old Company to pay a tax on its joint stock, which left it open to the forfeiture of its monopoly charter. ${ }^{35}$ The new Company, sensing that it had gained the upper hand, presented a petition to the crown on 13 April asking to be heard on the issue. ${ }^{36}$

It was suggested by Sir John Somers, who served as Lord Keeper, that the old Company failed to pay the tax on purpose in order to stop the regulation proceedings. ${ }^{37}$ The Court of Directors may have felt that better terms for a charter might be gained in the confusion of neither Company holding the rights to the trade. William's unwillingness to dissolve the old Company earlier, coupled with the advice of many of his ministers favouring the old Company, in all probability led Child and the old Company directors to force the issue by missing the deadline for the monopoly tax. Furthermore, the Parliamentary corruption proceedings held in $1695^{38}$ revealed that wide scale bribery of ministers and officials had been attempted by the old Company in 1693 to help secure a charter suitable to the latter's interests. The Company granted the King $£ 10,000$ and offered another $£ 50,000$, which he refused. Charges of old Company graft led to impeachment proceedings against Thomas, Duke of Leeds, who served as Lord President of the King's Council. ${ }^{39}$

The old Company also attempted to facilitate the granting of a new Parliamentary charter through bribery in the House of Commons. Josiah Child later reported to the House in the 1695 corruption proceedings on his involvement in bribery in 1693. He admitted "that a present of $£ 50,000$ should be made to the King, if his majesty would so far wave [sic] his prerogative, that an act of Parliament might be passed for settling the Company." 40 Thus, Child recognized that the King's word was no longer supreme in matters of foreign trade. William, however, would have nothing of it. Despite the offer of such a large sum, he was not willing to waive his rights entirely. The customs were still his main concern in the trade issue, and, without some right to regulate foreign trade, the crown would lose control of this source of revenue. As it happened, William was willing to recognize the need for Parliament to confirm any royal charter granted for the East India trade, but he would not surrender to Parliament his right to award such charters. 
The old Company spent over $£ 200,000$ to secure MPs to their cause. ${ }^{41}$ This sum was a sizeable fortune for the time, which Child and the Court of Committees hoped would secure the passage of a favourable new charter. While the issue of a charter remained unsettled, both the interloping and old Company ships were ordered to stay in port, completely halting the trade for a time and creating a sense of urgency for the crown. The King prorogued Parliament until the fall of 1693, however, in order to keep the Commons out of the negotiation process, fearing perhaps that they would force a new Company charter upon him, or that their mutual antipathy would prevent any constructive solutions.

The King was still reluctant to settle the East India trade upon the new Company, a fact borne out by his actions in October 1693 in re-establishing the old Company charter on virtually the same terms as before, while reserving the right to impose additional terms by Michaelmas 1694. ${ }^{42}$ The questions surrounding the East India trade and charter rights were no closer to resolution. On the one hand, the crown now had a way to impose adjustments to the charter - a development which favoured the new Company. On the other hand, William had no obligation to impose such measures, so lobbying by both the old and new Companies began in earnest.

William's East India Company charter was at best a temporary measure, which did little to end the deadlock. The old Company had been restored to its status as a monopoly, but William could force it to accept any or all of the new company proposals if he so chose. His response was, in effect, no response. The King hoped that the Companies would settle the trade amongst themselves, as they had done before the unfortunate joint stock tax issue. A settlement reached in this manner would leave the prerogative intact, as Parliament would not be involved. Such a peaceful arrangement, moreover, would resolve the trade and secure the customs revenue generated from the India trade indefinitely.

That the royal finances were in dire straits was made evident in a letter from Lord Godolphin to the King:

[I] am particularly directed by the Treasury to represent to you the great straits we are driven to there in order to carry on the indispensable services of the civil government, as well as those which relate to the war; and at this time especially we are sensible ... the expenses of your household abroad which require so much more than we are able to provide. ${ }^{43}$ 
The poor state of trade as a result of the war put pressure on the King's customs revenues. Godolphin wrote: "if the war continue, it will be impossible to save the customs." ${ }^{44}$ The East India trade was the least affected by the war and, therefore, very important to the crown. In 1691 , four ships alone brought in customs of $\pm 50,000 .{ }^{45}$ But the merchants of the new Company continued to "press very importunately that in such an unhappy juncture, when they are deprived of the Mediterranean trade and are such losers everywhere, the Queen [acting for William] would not exclude them from the trade of so great a part of the world."46

With the royal coffers so depleted, William needed the customs revenues secured; a settlement in favour of the old Company would guarantee these funds. Yet he could not ignore the petitions and pleas of the new Company merchants, who had great sums of money at their disposal to offer a cash-strapped crown. Therefore, new Company solicitations did not fall on completely unsympathetic ears. William had proposed measures for opening the East India trade during earlier sessions of Parliament and had realized the benefits of doubling the trading stock of the old Company as proposed in the regulations, which would also double the customs revenue from their ventures. Hence, the decision to put off the East India trade question seemed logical, in order to buy time for deciding an issue of such great import to both the crown and the nation as a whole.

William imposed his initial changes to the charter on 11 November. He empowered the Company to enlarge their trading capital with a new subscription of $£ 744,000$, which would allow new Company merchants to come into the trade under the old Company charter. The new conditions also placed restrictions upon the voting power of subscribers; each member holding $£ 1,000$ of stock received a vote, with a limit of ten votes. Finally, the joint stock was given a twenty-one year limit on its privileges. ${ }^{47}$

By changing the charter, William settled the issue according to the perceived wishes of the Commons majority. He now hoped that the trade would continue without controversy, allowing his customs revenues to be stabilized in the process. The old Company too was optimistic as this new charter left them on a solid footing while still allowing room for the new Company to enter the subscription. It appeared that Parliamentwould confirm the charter, and remove the spectre of instability that had loomed over the India trade since 1688. The royal prerogative over foreign trade was also protected, albeit in 
a weakened state, as the King had arranged the charter without Parliament. By proceeding in this way, William only recognized the need for Parliamentary confirmation on royal charters without allowing the Whitehall politicians the right to dictate their terms.

Yet, in the end, the new Company did not find the terms acceptable. Despite the opening of the new subscription and the voting restrictions placed on the share-holders, the complex arrangement left the old Company members with control of the trade. The new arrangement attracted a limited number of the interlopers but the principal members of the new Company syndicate continued to press their own cause. NewCompany supporters blocked Parliamentary confirmation of the charter and in January 1694 presented petitions in Parliament against the practices of the old Company.

The Commons was once again left to make a ruling on the East India trade. The new Company, led by long-time interloper and City Whig, Gilbert Heathcote, complained of Privy Council interference with their ships on behalf of the old Company. Heathcote's ship, the Redbridge, had been detained under such a Privy Council order. In response, a Committee of the Whole House was called on 6 January to consider the petitions. It was led by Thomas Papillon, a proponent of freer-trade from the pre-revolution days and an old nemesis of Josiah Child. The committee heard arguments for both sides, before ruling on 8 January that the detention of the Redbridge was illegal. Then on 15 January, in an unprecedented move, the Commitree carried a resolution by a vote of 91 to 90 declaring "that all the subjects of England have equal right to the East Indies unless prohibited by Act of Parliament." 48 The resolution was approved by the Lower House without a division on 19 January.

Not only was this resolution a blow to the old Company, it also adversely affected the royal prerogative. The Commons had openly attacked crown rights over foreign trade by removing the advantages provided by royal patents of monopoly. This apparent violation of the royal prerogative explains the extremely close vote in the Committee of the House. Many MPs still considered the prerogative sacred.

In March 1694, the belligerent tone of the Commons resolution prompted an offer from the old Company of a $£ 600,000$ interest-free loan in exchange for Parliamencary confirmation of their charter. Although supported in a committee of the House of Commons, it 
was rejected upon report to the House. Despite needing money to prosecute a war which it had sanctioned, the Lower House rejected the offer. In part, the rejection was due to claims that a new Company could provide an equal sum. Lord Coningsby, the Irish ViceTreasurer, provided another reason. He told the King that "those that pretend to be your friends [intend] to keep necessities always upon you," which was why the Commons refused "the reversion of the $£ 600,000$ upon the East India Company." 49 Coningsby warned the King of the Commons increasingly aggressive encroachments upon traditional Crown jurisdictions.

On 31 July 1694, Sir John Somers wrote to the King urging him to impose further qualifications on the old Company charter, largely in response to the 19 January resolution of the Lower House. By applying further regulations, he argued, the monarch would "keep your power on foor for some time longer," but "if nothing be done till after that time [29 September 1694], they are out of your power and stand again upon their old charter." was the realization that the charter must be made more suitable to the Commons - if it were not, no act confirming the charter would be forthcoming, and the trade would remain open along the lines of the 19 January 1694 Commons resolution.

Somers struck a chord. In an effort to bring the company more in line with the sentiments of the Commons majority, the King placed further restrictions upon the old Company charter by Letters Patent dated 28 September 1694. For example, the 24 members of the Court of Committees now had to be elected every year, and eight new members had to be among those elected. The Governor and DeputyGovernor could serve for no more than two years. Finally, the General Court was given more authority, including the power to appointall private committees and the ability to call a meeting of the General Court upon approval of only six voting members. ${ }^{\text {s1 William }}$ had, therefore, buckled under Parliamencary pressure to regulate the India trade. Although Somers suggested that any such action would protect the royal prerogative in relation to the Company, it was clearly a response to Parliamentary wishes.

The problems over the East India trade, however, still would not end. In March 1695, corruption proceedings began in a Committee of Lords and Commons involving charges of old Company bribery within the King's ministry. The hearings never reached a conclusion. 
William prorogued Parliament on 3 May 1695 and subsequently dissolved it on 11 October. The fact that the hearings were begun at all attests to the bitterness fostered by the India settlement. Parliament was bold to attack openly the King's ministers. William did not dissolve Parliament over the bribery inquiries alone, as the new Triennial Act (1694), itself a diminution of the prerogative, required a dissolution in a year and a half. But as Shrewsbury wrote in April 1695, the corruption proceedings "have thrown so much dirt that I conclude this same Parliament can never sit again." 52 Parliament was proving uncooperative to the monarch, by insisting on such measures as the Triennial Act, and William was concerned with extricating his ministry and himself from any implication in the corruption investigation. The King, therefore, exercised his prerogative to dissolve Parliament in the hopes that such issues would be dropped and a new House could concentrate on the supply which was needed for the war effort. This incident provides an example of the King's use of his prerogative to protect his power in relation to Parliament.

By the close of 1695, the state of England's trade was deteriorating. Privateering losses and the presence of the rival company in Scotland, ${ }^{53}$ suggested that the government was neglecting commercial interests. As a result, the proponents of freer trade, who once again dominated the Lower House, took a bold new path in settling the dispute over the right to govern trade and proposed a bill to form a Council of Trade. Such a bill was clearly a breach of the royal prerogative over trade, as it would take control of the nation's commerce and place it in the hands of a Parliamentary controlled body. As Matthew Tindal pointed out in his report of the proceedings on the council, it "was a debate plainly in a point of prerogative, how far the government should continue on its antient [ancient] bottom of monarchy, as to the executive part; or how far it should turn to a commonwealth." 54 The King realized the ramifications of such a measure and ordered his ministers to oppose it, although the Earl of Sunderland declared for the legislation. The royal prerogative once again seemed in danger of subversion. Fortunately for William, a surge of support for the crown, resulting from the disclosure of an assassination plot in February 1696, buried the ongoing debate over the Council of Trade.

After these momentous events, the issue of the East India trade seemed to fall into abeyance until the spring of 1697. On 23 March the old Company Governor, George Bohun, reported to the Court 
of Committees that he had been "sent for the last night to Whitehall [where] a proposal was made to him that a loan ... be made to his Majesty of $£ 400,000$ by this Company, to be secured on a good fund and to be repaid with interest within two years" and, in return, "an act of Parliament should be passed this session for settling the Company's trade to the East Indies." "s Although the proposal never achieved fruition, it is a further example of how the crown was willing to allow an encroachment on its prerogative rights in exchange for a sum of money.

December 1697 brought another attempt at a financial agreement, almost a decade after the idea of a new East India Company was first broached in Parliament. The old Company's leaders were approached "by persons of considerable rank in the government [on] how they stood disposed to advance a sum of money in consideration of a settlement by authority of Parliament. " 96 Governor Bohun was given a personal audience with the King, where he presented a plan to provide a loan of $£ 700,000$ at 4 per cent, and to revalue the old Company stock at 50 per cent to allow the new Company to subscribe into the trade. William appeared anxious to give the proposal a trial, as it would aid in settling the civil list. As a result the Company's offer was tabled in the Commons on 4 May $1698 .{ }^{57}$

The new Company responded with a proposal of its own, offering $£ 2,000,000$ at 8 per cent " on condition the Trade to India might be settled on the Subscribers, exclusive of all others," which was quickly sanctioned by the Commons. ${ }^{58} \mathrm{~A}$ preliminary subscription was organised, and by 17 May $£ 1.2$ million had been pledged. The King was at first sceptical, but the success of the subscription convinced him of the legitimacy of the new Company proposal. Moreover, the civil list that the Treasury Lords were able to offer William if the $£ 2$ million was accepted prompted Secretary of State Vernon to describe the monarch as having "never appeared in better humour."

In July 1698 the East India trade finally seemed settled when Parliament passed an "Act raising a sum not exceeding two million, upon a Fund for payment Annuityes, after the rate of $£ 8$ per cent per annum, and for settling the Trade to the East Indies," with divisions in the Commons numbering 115 to 78 and in the Lords 65 to $48 .{ }^{60}$ By 16 July subscriptions were closed, with the crown contributing $£ 10,000$. Within a week the old Company was given three years notice of its dissolution, after having also subscribed $£ 315,000$ to the new organization. 
By 5 September William granted a charter to "the English Company trading to the East Indies" and incorporated it as a joint stock. Within this new charter, the King recognized the new powers claimed by the Commons over trade. But the prerogative was saved in principle by the stipulation that the charter was issued in pursuance of a act of Parliament and "by virtue of our Prerogative Royal." ${ }^{2}$ This clause enabled the crown to save a shred of the prerogative of foreign trade in exchange for the finances which it so desperately needed. The transaction also suggests that the notion of King in Parliament was becoming more acceptable to the crown, with William assuming an important role in negotiating the terms of settlement.

All things considered, the East India question represented a constitutional and economic issue of paramount importance to William III. The debate called into question the extent of the royal prerogative over trade and laid the groundwork for a new relationship between Parliament and the King in such matters. Indeed, after analyzing the period between the accession of William and Mary and the chartering of the new Company, the King was willing to make sacrifices in the prerogative over foreign trade for expediency's sake. Put simply, William gave in to Parliamentary wishes on the East India question in order to assure the granting of subsidies for the war with France. These sacrifices were definitely made at the expense of the royal prerogative.

The lack of interest concerning the debate over the prerogative of foreign trade is curious considering that William's prerogative is of central importance to historians studying the period. The standard interpretation that the prerogative in general was left virtually untouched, with William holding a very strong position in his relations with Parliament, ${ }^{62}$ is rendered uncertain by the events discussed in this essay. The evidence points to a system of give and take, with William giving some power to Parliament in exchange for other political and economic benefits, such as a generous civil list and a high level of customs revenue. Thus, such struggles over chartered monopolies illustrate an attempt by the Commons to dictate national policy through control of the royal purse strings.

Yet the argument of Parliamencary supremacy triumphing over execurive power is not completely convincing either. Even in the area of foreign trade, William did not give in to Parliament outright. Although he did eventually give the old Company its three years 
notice in 1698, he did so on his terms. This action was a response to Parliamentary wishes, yet William immediately pressed for union between the two Companies and eventually achieved this goal in principle in 1702 . He also allowed the old Company to incorporate before their three years of grace expired, permitting them to trade indefinitely under their $£ 315,000$ in trading capital invested in 1698. This incorporation went against the wishes of the Commons majority, but the King allowed it in order to further his goal of a union, which he hoped would establish the India trade on a solid foundation once again. More importantly, Parliament recognized the monarch's right to incorporate the old Company, despite being against it in principle.

Thus, the East India question and its effect on the royal prerogative points to some middle ground between the traditional bifurcated views on the results of the Glorious Revolution. The example of the East India question perhaps fits better into the ideas of historians such as Richard Ashcraft, Lois Schwoerer, and Mark Goldie. ${ }^{63}$ They tend to present the Revolution settlement as a nonsettlement in a sense. The vague nature of the Bill of Rights left the positions of crown and Parliament uncertain, with radical Whigs attempting to restructure the constitution along the lines of Parliamencary supremacy. These Whigs had to fight with a King who still possessed much of his royal prerogative intact and was reluctant to allow encroachments into his privileges. This political situation created a constitutional bartering system, with William allowing the Whigs to intrude upon some of his powers in exchange for the money that would allow him to exercise his other prerogatives, most importandly that of waging war.

The changes in the royal prerogative brought abour by Parliamentary pressure can also be linked to William's idea of kingship. Perhaps his constitutional ideas can be traced back to his Dutch roots. The Dutch republic was a formidable trading nation, with a rather different view on how relations between traders and government were constitured. Of particular importance was the fact that the Dutch Company's monopoly was granted by the states general, not the stadholder. Therefore, William of Orange may have brought with him to England the idea that trade was the concern of the English counterpart of the states general, namely Parliament.

Finally, William's apparent lack of understanding about trading concerns may have led to his willingness to allow a Parliamentary 
invasion into the royal prerogative over foreign trade. William had little knowledge about the trading world of England or the Netherlands. This is supported by a letter written to the Earl of Portland, where he admitted that he was "not very well informed about the Indies." ${ }^{\text {" } 4}$ Once again, it becomes evident that William's concerns were essentially limited to the continent and the war with France. As long as his trading revenues were guaranteed, trade itself was of no significance to him.

Thus, the East India question opens the door for new research in the area of trade and the royal prerogative. It provides a middle ground between the conservative view of the Glorious Revolution merely confirming the constitution with only a change of succession and the more extreme nineteenth-century Whig view that a supreme Parliament was created. The state of the royal prerogative is very important to any scholarly treatment of William III's reign. Perhaps this study could lead to an examination of the relationships between prerogative, foreign policy, and trade. But for now we are left with a picture of a pragmatic King, who was willing to allow encroachments on his royal prerogative in exchange for secure revenues. 


\section{NOTES}

'Two superb studies, however, endure: W.R. Scott's Constitution and Finance of English, Scottish and Irish Joint Stock Companies to 1720, 3 vols., (Cambridge, 1912) and W.W. Hunter's A History of British India, 2 vols., (1899-1900). Both works make good use of sources available at the time, and cover a wide scope in a very thorough manner.

${ }^{2}$ Henry Horwitz, "The East India Trade, The Politicians, and the Constitution: 1689-1702," Journal of British Studies 18 (Spring, 1978), 1-18

${ }^{3}$ The former Whiggish view was eloquently expounded by Thomas Babbington Macauley in The History of England from the Accession of James II, 5 vols. (Cambridge, 1912) and more recently in E.N. Williams' The Eighteenth Century Constitution (Cambridge, 1960). For examples of the more conservative argument, see David Ogg, England in the Reign of James II and William III (Oxford, 1955); J. Kenyon, Revolution Principles, the Politics of Party 1689-1720(Cambridge, 1977); and J.R. Jones, Country and Court: England, 1658-1714 (Cambridge, Mass., 1978).

${ }^{4} A$ group of scholars has recently begun revising the scholarly perceptions of the state of the royal prerogative at this time. See Richard Ashcraft, Revolutionary Politics and Locke's "Two Treatises of Government"(Princeton, 1986); Lois G. Schwoerer, The Declaration of Rights, 1689 (Baltimore, 1981); and Mark Goldie, "The Roots of True Whiggism, 1688-94," History of Political Thought 1 (1980), 195-236.

'In that year a private act was passed, repealing a 1566 act which confirmed and extended the privileges granted to the Merchant Venturers of Bristol by royal patent. See D.H. Sacks, "Office and Calling: The Problem of Monopoly in Early Modern England," (Unpublished paper presented at the Clark Library Seminars, 6 April 1990, U.C.L.A.) 3-7.

'Narcissus Luttrell, A Brief Historical Relation of State Affairs, vol. 1 (Oxford, 1857), 538

'Horwiz, "The East India Trade," 3; Philip Lawson, The East India Company: A History (London, 1993), 53

${ }^{8}$ Calendar of State Papers Domestic (CSPD), May 1689, 129. Old style dates have been used throughout this paper, though with the year taken to begin on 1 January. 
${ }^{9} 21 \& 22$ Jac. I, c. 3, II. in Pickering, vol. 7, 256

${ }^{10} \mathrm{R}$. Y[ard] to Sir Joseph Williamson, 7 June 1689, in CSPD, 138 "The English Reports, LXXXIX, 496

${ }^{12}$ K.N. Chaudhuri, The Trading World of Asia and the English East India Company (Cambridge, 1978), 429

${ }^{13}$ Letter from the Court of Directors to Bombay, 31 January 1690 , in John Bruce, Annals of the Honourable East India Company, vol. 3 (London, 1810), 82

${ }^{14}$ From this point on, the interlopers will be referred to as the "new Company", while the chartered East India Company will be called the "old Company."

${ }^{15}$ Four East India ships provided $£ 50,000$ in customs in 1691 (Narcissus Luttrell, The Parliamentary Diary of Narcissus Luttrell 1691-1693, ed. Henry Horwicz [Oxford, 1972], 28 November 1691, 46)

${ }^{16}$ As cited in Henry Horwitz, Parliament, Policy and Politics in the Reign of William III (Newark, 1977), 75.

${ }^{17}$ Lutcrell, Parliamentary Diary, 173-76

${ }^{18}$ Notringham to Sir George Treby, 25 February 1692, Historical Manuscripts Commission, Finch MSS. IV, 15

${ }^{19}$ Chaudhuri, The Trading World of Asia, 430. For more on Josiah Child see William Letwin, Sir Josiah Child: Merchant Economist (Boston, 1959).

${ }^{20}$ Nottingham to Blathwayt, 21 June 1692, Finch MSS, IV, 251

${ }^{21}$ Ibid., 14 June 1692, 483

${ }^{22}$ Ibid., 251

${ }^{23}$ Blathwayt to Nottingham, 1 September 1692 Finch MSS. IV, 412 ${ }^{24}$ Notringham to Blathwayt, 21 June 1692 Ibid., 251

${ }^{25}$ Notringham to Blathwayt, 27 August 1692 Ibid., 423

${ }^{26}$ Nottingham to Blathwayt, 21 June 1692 Ibid., 251

${ }^{27} \mathrm{Gi}$ [lbert Burnet, bishop of] Sarum to [Nottingham], 3 September 1692 Ibid., 442

${ }^{28}$ Nottingham to Blathwayt, 27 August 1692 HMC, Finch MSS, 424 ${ }^{29}$ Lutcrell, Parliamentary Diary, entry for 24 November 1692, 258 9. No figures for this division are available.

${ }^{30}$ The terms agreed to are listed in Luttrell, Parliamentary Diary, entry for 10 December 1692, 308-9. Chaudhuri suggests that only $£ 250$ of stock were required to vote, as only 50 per cent of the operating capital was called. The Trading World of Asia, 611 n. 13. ${ }^{31}$ For more on this see Luttrell, Parliamentary Diary, 328. 
${ }^{32}$ Luttrell, Parliamentary Diary, entry for 22 February 1693, 436 ${ }^{33}$ [Lord Godolphin] to the King, [1693] cited in Williams, The Eighteenth Century Constitution 64-6

${ }^{34}$ Cited in Chaudhuri, The Trading World of Asia 431

$354 \& 5$ Will. \& Mary, c. 14, XII placed a five percent cax on the joint stock of the three great trading companies (the Hudson's Bay, Royal African, and the East India Companies) payable on March 25 (Pickering, vol. 9, 203.)

${ }^{36}$ Luttrell, A Brief Historical Relation of State Affairs, vol. 3, 15 April $1693,77-8$

${ }^{37}$ CSPD , 12 September 1693, 323-4

${ }^{38}$ These proceedings are discussed furcher on page 77-78 below.

${ }^{39}$ Cobbett, 915, 929, 933

${ }^{40}$ lbid., 929

"Ilbid., 900

${ }^{42}$ Luttrell, A Brief Historical Relation of State Affairs, Vol. 13, 23 September 1693, 191

${ }^{43}$ [Lord Godolphin] to the King, 19 May 1693 CSPD, 142

${ }^{44}$ [Lord Godolphin] to the King, [1693], as cited in Williams, The Eighteenth Century Constitution 64

${ }^{45}$ Luttrell, Parliamentary Diary, entry for 28 November 1691, 46

${ }^{46}$ Somers to the King, 12 September 1693, CSPD 324

${ }^{47}$ Bruce, Annals, vol. 3, 134

${ }^{48}$ Journals of the House of Commons (CJ), 6, 8, 19 January 1694;

Horwitz, Parliament, Policy, 130

${ }^{49}$ Cited in Henry Horwiz, "The East India Trade" 7

${ }^{50}$ Somers to the King, 31 July 1694 CSPD, 246

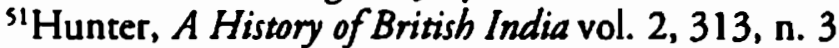

'52 Shrewsbury Correspondence, 226; as cited in Horwitz, Parliament, Policy, 155

${ }^{33}$ William, acting as king of Scotland, had given this Company a royal charter, perhaps in order to preserve the trade in some form while the English rivals battled for supremacy. The Scottish Company was doomed to failure, however, partly due to English pressure and partly due to the failure of the Darien scheme. For more on the Scottish East India Company see: Linda Kerr, "Background to Union: The Scotrish Economy, 1660-1717 Reconsidered," (MA thesis, University of Calgary, 1987), or W.R. Scotc, Constitution and Finance (Gloucester, 1968)

${ }^{54} \mathrm{LJ}, 978$ 
86 Past Imperfect

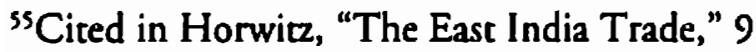

${ }^{56}$ Ibid., 10

57Ibid.

${ }^{58}$ Cobbett, 1178

${ }^{59}$ CSPD , 1698, 272

${ }^{60}$ Cobbett, 1180

${ }^{6}$ As cited in Hunter, A History of British India 320

${ }^{62}$ See note 2

${ }^{63}$ See note 4.

${ }^{64}$ Andrew Lossky, "Political Ideas of William III," in Herbert H. Rowen and Andrew Lossky, Political Ideas and Institutions in the Dutch Republic (Los Angeles, 1985), 53 